\title{
Does restoring native forest restore ecosystem functioning? Evidence from a large-scale reforestation project in the Scottish Highlands
}

\author{
Emily Warner ${ }^{1,2}$ (D), Owen T. Lewis ${ }^{3}$ (D) Nick Brown $^{1}$ (D), Rowan Green ${ }^{1,3,4}$ (D), Alan McDonnell ${ }^{5}$, \\ Doug Gilbert $^{5}$, Andy Hector ${ }^{1}$ (D)
}

Given the worldwide plans for extensive tree planting, we urgently need to understand how and where implementation will contribute to goals such as those for carbon sequestration. We used a long-term, large-scale native reforestation project in the Scottish Highlands to assess the response of carbon storage and other ecosystem functions to reforestation and grazing exclusion. We measured aboveground carbon, topsoil carbon, topsoil nitrogen, decomposition rates, soil invertebrate feeding activity, tree regeneration, and ground-layer and moss height at $\mathbf{1 4}$ sites that are in the early stages of reforestation and fenced to exclude grazing. Reforestation areas were compared to unforested and mature forest areas that are both grazed and ungrazed, using $10 \times 10 \mathrm{~m}$ plots. Aboveground carbon in the reforestation plots $\left(1.4 \mathrm{~kg} / \mathrm{m}^{2}\right.$ [95\% CI: $0.6,2.6$, average age 20 years since reforestation) was c. $8 \%$ of the mature forest plots $\left(17.1 \mathrm{~kg} / \mathrm{m}^{2}[13.1,21.8]\right)$. Topsoil carbon was lower in the reforestation plots $\left(18.78 \mathrm{~kg} / \mathrm{m}^{2}[11.79,25.78]\right)$ than in the unforested $\left(29.82 \mathrm{~kg} / \mathrm{m}^{2}[24.34,35.29]\right)$ or mature forest $\left(31.39 \mathrm{~kg} / \mathrm{m}^{2}[22.91,39.88]\right)$ plots. Responses of other functions to the reforestation and grazing interventions varied. Our results suggest that reforestation may trigger carbon loss from areas with high initial soil carbon even with low disturbance establishment, at least in the short term. Our work emphasizes where we lack knowledge: on the potential for long-term re-accumulation of soil carbon under semi-natural native reforestation, soil carbon sequestration in the deeper soil layers, and the response of soil carbon to natural regeneration.

Key words: ecosystem functioning, forest expansion, forest restoration, reforestation, soil carbon

\section{Implications for Practice}

- Loss of soil carbon may occur even with low-density native reforestation, established with low disturbance techniques. This emphasizes a need to understand routes of soil carbon loss during the early stages of reforestation, particularly the role of biotic processes.

- Changes in ecosystem functions documented in tree planting experiments may not be observed or may take longer to emerge under the less-controlled conditions of actual reforestation projects.

- In future reforestation projects, baseline soil carbon surveys and ongoing monitoring of carbon accumulation are recommended to ensure accurate carbon accounting and to provide a clearer understanding of the soil carbon trajectory after reforestation.

\section{Introduction}

There is a global pledge to restore 350 million hectares of degraded forest, with multiple anticipated benefits, including carbon storage, biodiversity conservation, and livelihood enhancement (Dave et al. 2017). Forest expansion receives particular attention as a climate change mitigation strategy (Seddon et al. 2019). Given these initiatives, we urgently need scientific research on how reforestation can best be done and where it is most effective (Di Sacco et al. 2021).

In the United Kingdom, the Committee on Climate Change recommends planting c. 30,000 ha a year to increase tree cover to $17 \%$ by 2050 and contribute to the country's net-zero target (Committee on Climate Change 2020). Forest cover in the

Author contributions: EW conceived the idea and led the analysis and writing; EW, OL, AH, NB designed the study and analysis; AM, DG helped to define the research focus and provided background information; EW, RG collected the data; all authors contributed to manuscript drafts and approved the final version.

${ }^{1}$ Department of Plant Sciences, University of Oxford, Oxford, U.K

${ }^{2}$ Address correspondence to E. Warner, email emily.warner@ plants.ox.ac.uk

${ }^{3}$ Department of Zoology, University of Oxford, Oxford, U.K.

${ }^{4}$ Department of Life Sciences, University of Manchester, Manchester, U.K.

${ }^{5}$ Trees for Life, Findhorn Bay, Forres, U.K.

(C) 2021 The Authors. Restoration Ecology published by Wiley Periodicals LLC on behalf of Society for Ecological Restoration.

This is an open access article under the terms of the Creative Commons Attribution License, which permits use, distribution and reproduction in any medium, provided the original work is properly cited.

doi: $10.1111 /$ rec. 13530

Supporting information at:

http://onlinelibrary.wiley.com/doi/10.1111/rec.13530/suppinfo 
United Kingdom is currently c. $13 \%$, rising from a minimum of c. $5 \%$ at the beginning of the 20th century, covering $19 \%$ of Scotland, $15 \%$ of Wales, $10 \%$ of England, and $9 \%$ of Northern Ireland (Forest Research 2020). The U.K. government has so far failed to meet annual planting targets; in 2019-2020 only 13,660 ha of new forest was planted, more than $80 \%$ of which was in Scotland, where historically forest expansion has occurred most rapidly in the United Kingdom (Forest Research 2020; HM Government 2020).

An analysis of global reforestation pledges suggests that restoring natural forest would store up to 42 times more carbon than plantation forest and provide greater co-benefits, such as habitat for associated native species (Lewis et al. 2019). A key portion of forest carbon is stored in the soil, c. $60 \%$ of total carbon in temperate forests, with forest soils storing close to half of global terrestrial organic carbon (Mayer et al. 2020). Forest restoration and expansion for climate change mitigation intends to enhance existing stores of carbon, but the outcome will depend on the location and type of forest establishment (Matthews et al. 2020). With forest growth carbon accumulation occurs aboveground, but the net outcome depends on the rate of tree growth and changes to soil carbon. Prior land-use influences this: afforestation of former cropland leads to the greatest carbon accumulation, whereas forest establishment on peatland leads to carbon losses (Thomas et al. 2015). Soil disturbance during forest establishment can drive net carbon losses, but can potentially be compensated for by carbon accumulation aboveground and inputs belowground with tree growth (Vanguelova et al. 2013; Mayer et al. 2020).

It is widely recognized that forest establishment on deep peat (depth more than $50 \mathrm{~cm}$ ) leads to overall carbon losses through soil disturbance and drying (Morison et al. 2012; Vanguelova et al. 2018). The outcome on shallow peats is less well understood (Vanguelova et al. 2018). Semi-natural forest, which will not be disturbed by harvesting, might provide a more certain carbon stock on these soil types, but modeling suggests that due to slower growth it takes longer to re-accumulate carbon lost during initial disturbance (Matthews et al. 2020). Even with low disturbance planting, native reforestation on carbon-rich soils can result in no net carbon storage after 39 years, as a consequence of soil carbon losses (Friggens et al. 2020). In the United Kingdom, soil carbon stocks are 86 times greater than the vegetation carbon store and the most carbon-rich soils are disproportionately found in Scotland (Milne \& Brown 1997; Vanguelova et al. 2018). The Scottish uplands provide opportunities for forest expansion; however, carbon-rich soils occur in the uplands and there is mixed evidence on the impact of reforestation on net carbon balances in these areas (Vanguelova et al. 2018; Friggens et al. 2020; Matthews et al. 2020).

Assessing the impact of forest expansion requires more than quantification of aboveground and belowground carbon stocks. It is important to monitor how other ecosystem functions respond, giving a wider view of the value of the new habitat for humans and other organisms (Kollmann et al. 2016). Tree establishment on heather moorland has been shown to influence belowground properties and processes, altering soil structure and functions, for example, by increasing nutrient availability, decomposition rates, and the abundance of soil fauna (Mitchell et al. 2007; Kollmann et al. 2016). Aboveground, the structure and composition of the vegetation determines habitat provision and the future of a reforested ecosystem depends on tree regeneration (Mitchell et al. 2012; Patterson et al. 2014). To provide a more holistic understanding of the impact of forest establishment, we measured soil nitrogen, decomposition rates, soil invertebrate feeding, tree regeneration, and vegetation structure. Changes in decomposition rates provide additional background to understand any changes in soil carbon and soil nutrient availability, which will be indicated by soil nitrogen levels. Soil invertebrate feeding provides a proxy to assess the abundance and activity of the soil fauna community. Tree regeneration is crucial to the continued development of the reforestation sites. Finally, we measured vegetation structure to quantify habitat provision and responses to grazing exclusion; in the Scottish Highlands, high deer numbers generally prevent tree regeneration, such that grazing exclusion is necessary to facilitate forest restoration (Tanentzap et al. 2013).

We used a long-term large-scale native reforestation project in the Scottish Highlands to assess the effect of grazing exclusion and native reforestation on carbon storage and a suite of other ecosystem functions. Given that existing data on native reforestation in this context are primarily from experimental studies (e.g. Mitchell et al. 2007; Friggens et al. 2020), we use a conservation-focussed reforestation project that reflects likely future native reforestation in the Scottish uplands. Comparisons were made between ungrazed, reforestation sites, and unforested and mature forest areas that are both grazed and ungrazed. We assessed (1) the impact of forest status (unforested, reforestation, mature) and grazing (grazed, ungrazed) on aboveground and topsoil carbon storage; (2) the impact of the forest and grazing treatments on topsoil nitrogen, decomposition rates, soil invertebrate feeding, tree regeneration, and vegetation structure; and (3) the effect of reforestation site age on aboveground and topsoil carbon storage.

\section{Methods}

\section{Study Area}

The reforestation sites are located in Glen Affric $\left(57^{\circ} 12^{\prime} 50^{\prime \prime} \mathrm{N}\right.$, $05^{\circ} 13^{\prime} 48^{\prime \prime} \mathrm{W}$ to $57^{\circ} 17^{\prime} 15^{\prime \prime} \mathrm{N}, 004^{\circ} 56^{\prime} 04^{\prime \prime} \mathrm{W}$ ) and Glen Moriston $\left(57^{\circ} 12^{\prime} 28^{\prime \prime} \mathrm{N}, 004^{\circ} 50^{\prime} 54^{\prime \prime} \mathrm{W}\right.$ to $\left.57^{\circ} 13^{\prime} 23^{\prime \prime} \mathrm{N}, 004^{\circ} 43^{\prime} 32^{\prime \prime} \mathrm{W}\right)$, adjacent glens in the Scottish Highlands (Fig. S1) (Warner et al. 2021). These landscapes contain multiple habitats, including mature Caledonian pinewood, productive conifer plantations, unforested heathland, and regenerating native forest. The unforested parts of the wider landscape are thought to have experienced a decline in forest cover driven by human and climatic influences from c. 3,800 years ago (Tipping et al. 2006). The mature forest is part of one of the largest Caledonian pinewood remnants, with trees up to 260 years old (Mason et al. 2004). Our study used 14 reforestation sites that were planted and fenced to exclude grazing, predominantly by Red, Roe, and Sika deer (Cervus elaphus, Capreolus capreolus, and 
Cervus nipon) and feral Wild boar (Sus scrofa). The sites were established between 1990 and 2012 by Trees for Life, Forestry Commission Scotland, and the National Trust for Scotland (Table S1). We classified the fenced areas as "ungrazed," although as permeability to deer increases as the fences age, grazing is reduced rather than totally excluded at most "ungrazed" sites. Reforestation sites were replanted with native Caledonian pinewood species, cultivated from local provenance seed (Table S1). At each site, planting was predominantly targeted to well-drained areas, with some wet areas planted with Alnus glutinosa and Salix spp. Tree cover at each site is heterogeneous, as the success of tree establishment varied depending on drainage and topography. Further information on the study system including biodiversity data is reported by Warner et al. (2021).

\section{Study Design}

Our study has a fractional factorial design in which combinations of two treatments are replicated across multiple locations. Sites are the 14 locations where reforestation has occurred, with nearby unforested reference habitat present at each site. All possible combinations of the treatments forest status (unforested, reforestation, mature) and grazing status (grazed, ungrazed) are represented in our study, excluding reforestation $\times$ grazed, which does not exist because tree regeneration is suppressed by deer grazing in the wider landscape. $10 \times 10 \mathrm{~m}$ plots were established within each treatment combination (Table 1, Fig. S2). In the study landscape, mature Caledonian pinewood is of limited extent. Mature forest was therefore only associated spatially with three reforestation sites. Grazed and ungrazed mature forest plots were established at these three sites and a further two pairs of grazed and ungrazed mature forest plots at two of the sites, at least $500 \mathrm{~m}$ from the other mature forest plots, in non-contiguous areas of mature forest (Fig. S1). This gave a total of five pairs of ungrazed and grazed mature forest plots (Table 1). This design allowed the effect of forest (unforested, reforestation, mature) and grazing (ungrazed, grazed) status on the ecosystem functions to be assessed.

As reforestation success was heterogeneous, plots were placed to represent the best-case scenario of forest establishment at a site (reforestation, ungrazed). At each site, an unforested, grazed plot was established, at the nearest location to the reforestation, ungrazed plot, matched on topography, aspect, and elevation. A plot in the nearest unforested, ungrazed area was also established at each site. Plots in the mature forest were matched to the reforestation and unforested plots at these sites. At each site, the plots were $30-400 \mathrm{~m}$ apart.

Table 1. Sample sizes in each forest $\times$ grazing category for the ecosystem functions measured. *At two sites, it was not possible to extract soil cores, so for soil carbon and nitrogen the sample size is 12 .

\begin{tabular}{lccc}
\hline & Unforested & Reforestation & Mature \\
\hline Ungrazed & $14^{*}$ & 14 & 5 \\
Grazed & $14^{*}$ & & 5 \\
\hline
\end{tabular}

\section{Aboveground Tree Carbon}

The diameter at breast height (dbh) was recorded for every tree with dbh greater than $2.5 \mathrm{~cm}$ in each plot. For multi-stemmed species, every stem greater than $2.5 \mathrm{~cm}$ dbh was recorded. Plot level estimates of aboveground biomass were calculated using species-specific allometric equations (Table S2). Betula and Salix spp. were identified to genus level, and the allometric equations developed for Betula pendula and Salix caprea were used. For Sorbus aucuparia and S. caprea, equations for aboveground biomass were not available, so allometric equations for stem biomass were used. Where multiple allometric equations were available an equation developed in the United Kingdom or with the highest $R^{2}$ value was used (Zianis et al. 2005; Muukkonen \& Mäkipää 2006). Biomass was converted to carbon $\left(\mathrm{kg} / \mathrm{m}^{2}\right)$ based on carbon concentrations of $49 \%$ for broadleaves and 50\% for conifers (Matthews 1993).

\section{Topsoil Carbon and Nitrogen}

Soil samples were taken using a $3-\mathrm{cm}$ diameter soil corer from the top $10 \mathrm{~cm}$ of the soil, directly below any undecomposed litter. Soil was sampled at this depth as the surface layers were expected to be most sensitive to the change in land use. At two unforested, ungrazed plots and two unforested, grazed plots, it was not possible to extract intact soil cores due to the wet ground, so the sample sizes for these two categories are $n=12$. Three cores per plot were homogenized to provide a sample for analysis of total carbon and nitrogen and three additional cores were used to calculate bulk density. The height of each bulk density core was measured to the nearest mm on sampling. The samples for carbon and nitrogen analysis were air dried to remove residual moisture and sieved using a $2 \mathrm{~mm}$ sieve. The air dried and sieved samples were sent to Forest Research, Alice Holt Lodge, Surrey, U.K., for analysis. Percentage soil carbon and nitrogen were estimated simultaneously by combustion using a Carlo Erba CN analyzer (Flash1112 series), following the ISO 10694 protocol (International Organization for Standardization 1995) and the ISO 13878 protocol (International Organization for Standardization 1998). Samples were ball milled for homogenization at mg level. Approximately $30 \mathrm{mg}$ of milled soil was weighed in a tin capsule using a sixdecimal balance and then pressed, before being analyzed. The bulk density samples were dried at $105^{\circ} \mathrm{C}$ for 24 hours and sieved through a 2-mm sieve; bulk density $\left(\mathrm{g} / \mathrm{cm}^{3}\right)$ was calculated based on the dry weight of the sample and the volume of soil collected. Bulk density and percentage soil carbon and nitrogen were used to estimate soil carbon and nitrogen stocks $\left(\mathrm{kg} / \mathrm{m}^{2}\right)$ in the top $10 \mathrm{~cm}$ of the soil in each grazing $\times$ forest category.

\section{Decomposition Rate}

The decomposition rate constant, $k$, was calculated using the Tea Bag Index (Supplement S1) (Keuskamp et al. 2013). In each plot, six pairs of teabags (faster decomposing green tea and slower rooibos) were buried at $8 \mathrm{~cm}$ depth in random locations. Prior to burial, the bags were weighed. The bags were left buried 
for a minimum of 54 and up to 67 days (mean $\pm \mathrm{SE}$, $61.6 \pm 0.17$ days). On collection, the bags were dried at c. $70^{\circ} \mathrm{C}$ for 2 hours and subsequently air dried for 48 hours to stop the decomposition process. Prior to weighing to estimate the final mass of the bags, they were dried at $70^{\circ} \mathrm{C}$ for 24 hours.

\section{Soil Invertebrate Feeding}

Soil faunal feeding was measured in the top $12 \mathrm{~cm}$ of the soil using bait lamina (Terra Protecta $\mathrm{GMbH}$, Berlin, Germany). Bait lamina are PVC strips $\left(1 \times 6 \times 120 \mathrm{~mm}^{3}\right)$ with 16 $1.5 \mathrm{~mm}$ perforations that are impregnated with a bait substrate composed of cellulose powder, wheat bran, and activated charcoal (70:23:7) (Kratz 1998). In each plot, six bait laminae were inserted into the soil in a $3 \times 2$ grid with $3 \mathrm{~cm}$ spacing. At 15 days, two strips were removed to assess the appropriate exposure period. After 30 days, the remaining bait laminae were removed. Feeding activity at each perforation was recorded if light penetrated the bait material. For analysis, feeding was assessed at the level of each bait lamina stick, generating a binary response variable: feeding or no feeding, using the four bait sticks assessed at day 30 .

\section{Tree Regeneration}

In each plot, all young trees with dbh less than $2.5 \mathrm{~cm}$ were recorded in the height categories: $<50,50$ to $<100,100$ to $<150$, and $\geq 150 \mathrm{~cm}$, for each species.

\section{Ground-Layer and Moss Height}

Three $1 \times 1 \mathrm{~m}$ quadrats were placed randomly in each plot. The height of the ground vegetation and depth of the moss layer were measured at five points evenly distributed across the diagonal of the quadrat.

\section{Data Analysis}

All statistical analysis was carried out using $\mathrm{R}$ ( $\mathrm{R}$ Core Team 2019). The study design is a fractional factorial combination of the two factors forest (unforested, reforestation, mature) and grazing (grazed, ungrazed), where the grazed $\times$ reforestation combination is absent (Table 1). Linear and generalized mixed-effect models were fitted using the package lme 4 (Bates et al. 2015), testing fixed effects for forest (unforested, reforestation, mature) and grazing (grazed, ungrazed), and the forest $\times$ grazing interactions on each ecosystem function (Table 2, Table S3), with a random effect for site (a factor with 16 levels). Where the forest $\times$ grazing status interaction was not significant, it was removed from the model for simplicity, this was the case in all models except the tree regeneration model. As the unforested plots contained no trees with dbh greater than $2.5 \mathrm{~cm}$, the analysis of aboveground tree carbon only included the reforestation and mature forest treatments. An extreme outlier ( $k=0.091$ ) was removed from the decomposition rate constant dataset; all other values fell in the range $0.0076-0.035$ and this result is assumed to reflect a data processing error. To test the effect of time since reforestation on aboveground tree and topsoil carbon,
Table 2. The model structures used in the analysis of each ecosystem property. Models to assess the effect of time since reforestation on tree carbon, topsoil carbon, and the topsoil carbon difference were fitted using data from the reforestation sites only. Response variables are given to the left of the tilde $(\sim)$, fixed effects for explanatory variables on the right, and random effects for (nested) design variables within parentheses.

\begin{tabular}{|c|c|c|}
\hline Model & Units & Error Structure \\
\hline $\begin{array}{l}\text { sqrt }(\text { tree carbon }) \sim \text { forest }+ \\
\text { grazing }+(1 \mid \text { site })\end{array}$ & $\mathrm{kg} / \mathrm{m}^{2}$ & Normal \\
\hline $\begin{array}{l}\text { Topsoil carbon } \sim \text { forest }+ \\
\text { grazing }+(1 \mid \text { site })\end{array}$ & $\mathrm{kg} / \mathrm{m}^{2}$ & Normal \\
\hline $\begin{array}{l}\text { Topsoil nitrogen } \sim \text { forest }+ \\
\text { grazing }+(1 \mid \text { site })\end{array}$ & $\mathrm{kg} / \mathrm{m}^{2}$ & Normal \\
\hline $\begin{array}{l}\text { Decomposition rate constant } \\
\qquad(k) \sim \text { forest }+ \text { grazing }+ \\
\quad(1 \mid \text { site })\end{array}$ & & Normal \\
\hline $\begin{array}{l}\text { Feeding versus no feeding } ~ \\
\text { forest }+ \text { grazing }+(1 \mid \text { site } / \\
\text { plot })\end{array}$ & & Binomial (logit link) \\
\hline $\begin{array}{l}\text { Seedlings per plot } \sim \text { forest } \times \\
\quad \text { grazing }+(1 \mid \text { site })\end{array}$ & & Poisson (log link) \\
\hline $\begin{array}{l}\text { Ground-layer height } \sim \text { forest }+ \\
\text { grazing }+(1 \mid \text { site })\end{array}$ & $\mathrm{cm}$ & Normal \\
\hline $\begin{array}{l}\text { Moss depth } \sim \text { forest }+ \\
\text { grazing }+(1 \mid \text { site })\end{array}$ & $\mathrm{cm}$ & Normal \\
\hline $\ln ($ tree carbon $) \sim$ site age & $\mathrm{kg} / \mathrm{m}^{2}$ & Normal \\
\hline $\ln ($ soil carbon $) \sim$ site age & $\mathrm{kg} / \mathrm{m}^{2}$ & Normal \\
\hline $\begin{array}{l}\text { Topsoil carbon } \sim \text { plot type }+ \\
\quad(1 \mid \text { site })\end{array}$ & $\mathrm{kg} / \mathrm{m}^{2}$ & Normal \\
\hline $\begin{array}{l}\text { Topsoil carbon difference } \\
\text { reforestation, ungrazed } \\
\text { versus unforested, } \\
\text { grazed } \sim \text { site age }\end{array}$ & $\mathrm{kg} / \mathrm{m}^{2}$ & Normal \\
\hline
\end{tabular}

linear models were fitted using the chronosequence of reforestation plots (Table 2). Additional analyses of the topsoil carbon data were carried out: linear models were used to test the effect of plot type (a factor with five levels representing each forest $\times$ grazing combination) on topsoil carbon and the effect of site age on the difference in topsoil carbon between reforestation, ungrazed and unforested, grazed plots at each site. Where estimates and 95\% confidence intervals are given for levels of the forest or grazing treatment alone, these were derived from models fitted with the forest or grazing term only.

\section{Results}

\section{Carbon Storage}

Aboveground tree carbon was an order of magnitude higher in mature forest plots $\left(17.1 \mathrm{~kg} / \mathrm{m}^{2}\right.$ [95\% CI: 13.1, 21.8]) than in the reforestation plots $\left(1.4 \mathrm{~kg} / \mathrm{m}^{2}[0.6,2.6]\right.$, average age 20 years since reforestation) (Fig. 1A). There was no effect of grazing on aboveground tree carbon (grazed, mature $16.5 \mathrm{~kg} / \mathrm{m}^{2}$ [11.1, 22.9] vs. ungrazed, mature $17.9 \mathrm{~kg} / \mathrm{m}^{2}$ $[12.2,24.6])$. Aboveground tree carbon accumulated over the chronosequence of reforestation sites, with a clear relationship between aboveground tree carbon and time since reforestation (effect of age on $\ln$ (tree carbon) 0.13 [0.06, 0.2]) (Fig. 2A). 
(A)

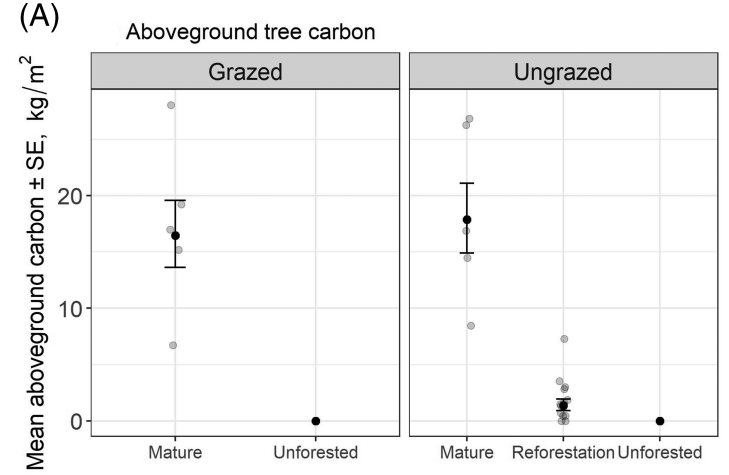

(C)
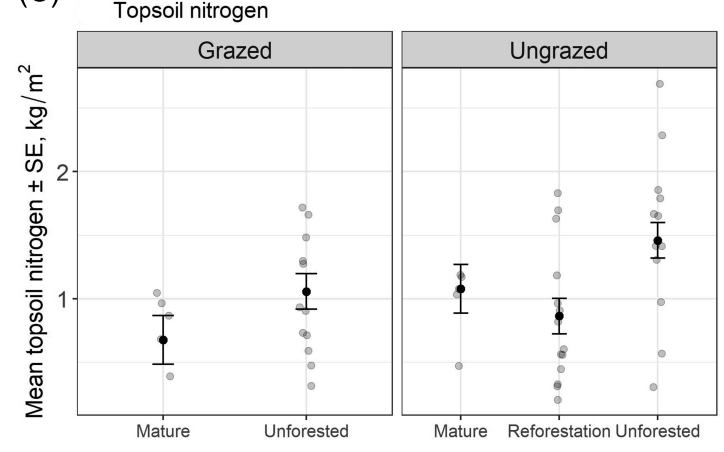

(E)

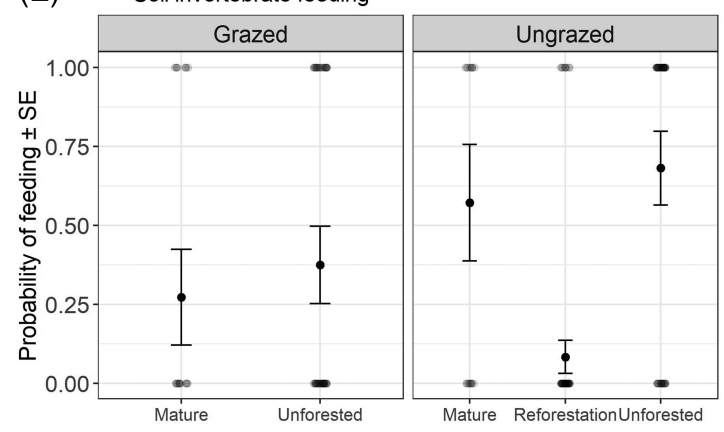

(G)

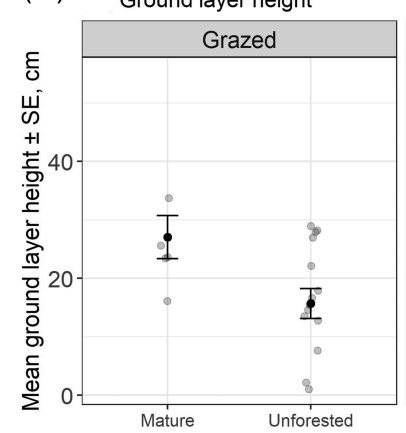

(B)

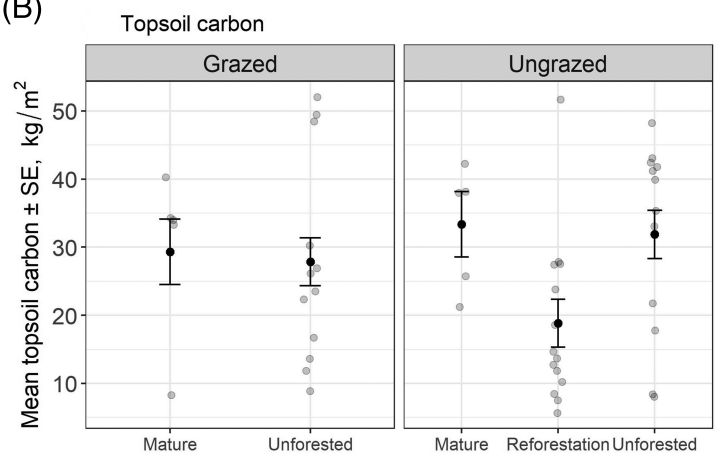

(D)

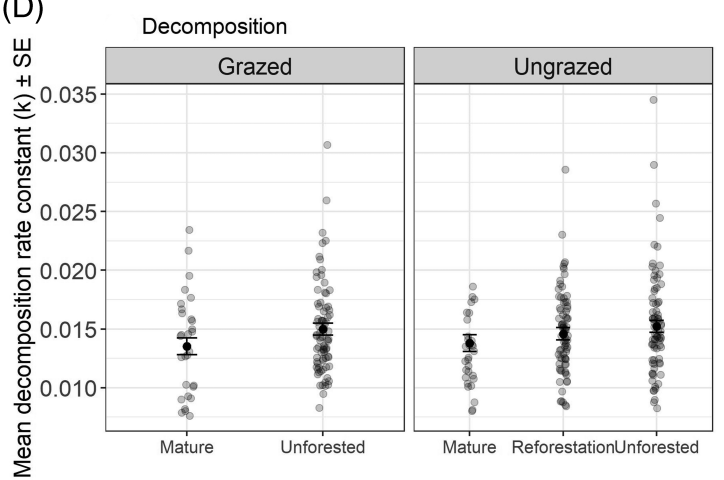

(F) Seedling regeneration

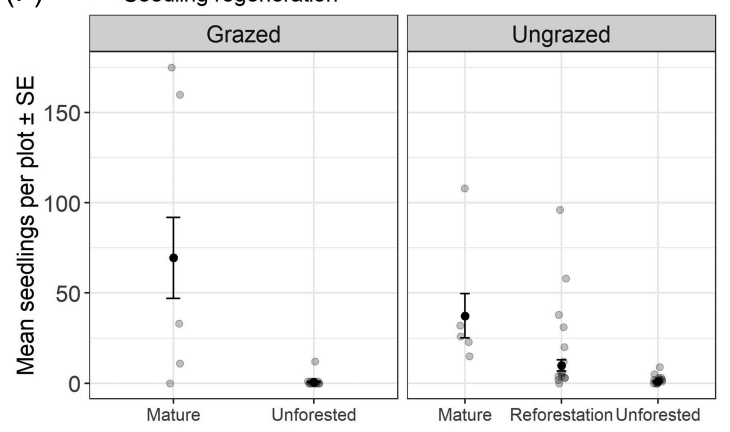

(H)

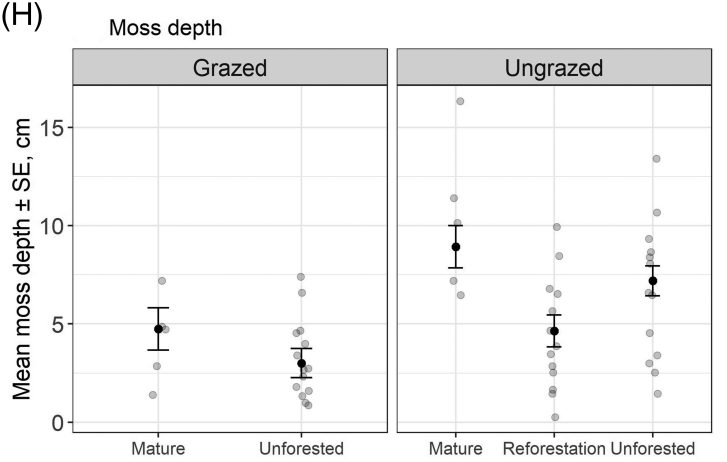

Figure 1. The response of each measured variable to the forest $\times$ grazing treatments. (A) Aboveground tree carbon, (B) topsoil carbon, (C) topsoil nitrogen, (D) decomposition rate, $(E)$ soil invertebrate feeding, $(F)$ seedling regeneration, $(\mathrm{G})$ ground-layer height, and $(\mathrm{H})$ moss depth. Estimates and $\pm \mathrm{SEs}$ were extracted from the models. 

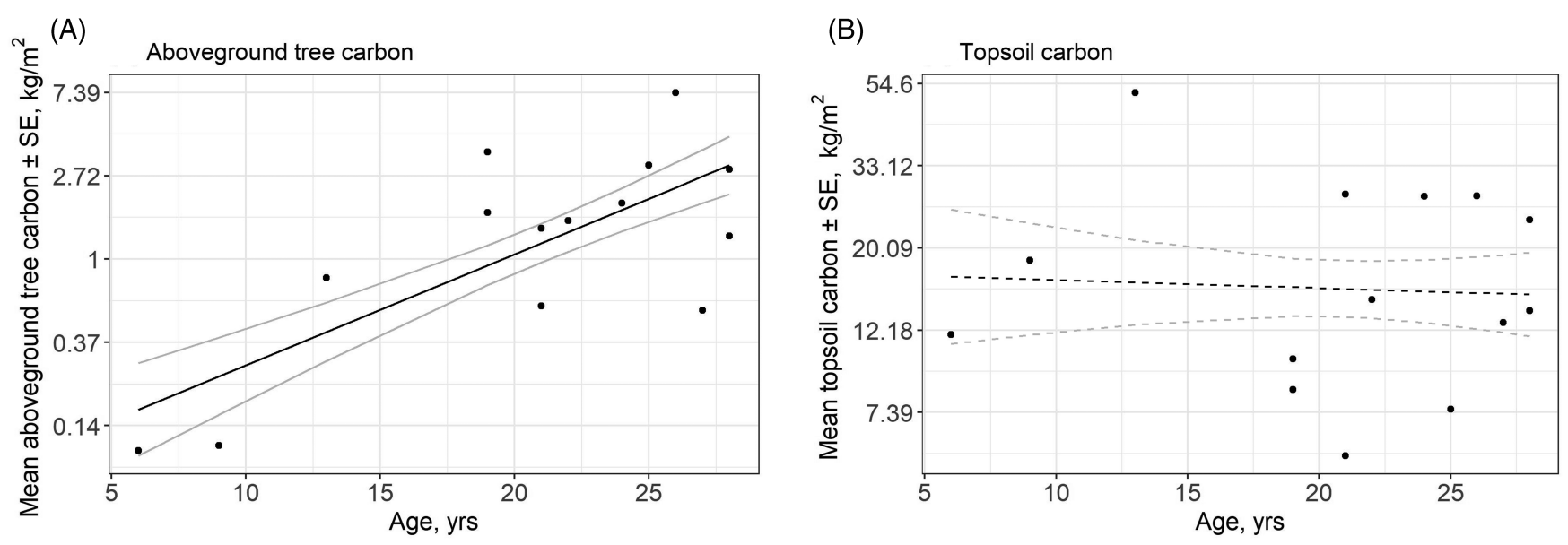

Figure 2. Changes with time-since-reforestation (A) aboveground tree carbon and (B) topsoil carbon across the chronosequence of reforestation plots (logscales). Nonsignificant trends are shown with dashed lines.

Topsoil carbon was lower in the reforestation plots $\left(18.78 \mathrm{~kg} / \mathrm{m}^{2}\right.$ $[11.79,25.78])$ than in the mature forest $\left(31.39 \mathrm{~kg} / \mathrm{m}^{2}\right.$ [22.91, 39.88]) and unforested $\left(29.82 \mathrm{~kg} / \mathrm{m}^{2}\right.$ [24.34, 35.29]) plots (Fig. 1B). There was no effect of the grazing treatment on topsoil carbon $\left(4.02 \mathrm{~kg} / \mathrm{m}^{2}[-4.69,12.73]\right)$. When comparing topsoil carbon by plot type, the difference between reforestation, ungrazed and unforested, grazed plots was less clear $\left(8.83 \mathrm{~kg} / \mathrm{m}^{2}[-1.37\right.$, 19.02]) (Fig. S3A). There was no clear effect of time since reforestation on topsoil carbon (effect on $\ln$ (topsoil carbon) -0.0049 $[-0.056,0.046])($ Fig. 2B) or on the difference in topsoil carbon between the reforestation, ungrazed and unforested, grazed plots (effect on topsoil carbon difference $0.38[-1.13,1.89]$ ) (Fig. S3B), suggesting no accumulation of soil carbon over the chronosequence.

\section{Soil Properties and Processes}

Soil nitrogen was higher in the ungrazed plots than the grazed plots (mean difference $0.40 \mathrm{~kg} / \mathrm{m}^{2}$ [95\% CI: $\left.0.062,0.74\right]$ ) (Fig. 1C). Soil nitrogen was higher in the unforested plots than the reforestation plots $\left(0.60 \mathrm{~kg} / \mathrm{m}^{2}[0.22,0.97]\right)$.

The decomposition rate was higher in the unforested plots $(0.0151[0.0142,0.0160])$ than mature forest plots $(0.0136$ $[0.0123,0.0150])$ (Fig. 1D). There was no clear difference in the decomposition rate in the reforestation plots $(0.0146$ $[0.0135,0.0157])$ compared to mature and unforested plots.

Soil invertebrate feeding activity was lower in the reforestation plots $(0.080[0.021,0.26])$ than in the mature $(0.42[0.15,0.75])$ or unforested $(0.53[0.32,0.73])$ plots, and higher in ungrazed than grazed plots (Fig. 1E).

\section{Tree Regeneration and Ground Layer Vegetation Structure}

Tree regeneration was higher in the mature forest (54 seedlings per plot [95\% CI: 19, 89]) and reforestation plots $(9[3,14])$ than in the unforested plots $(1[0.5,2])$ (Fig. 1F). There was an interaction between grazing and forest status; the grazed mature plots had more seedlings than the ungrazed mature plots $(70[24,116]$ vs. $38[13,62])$. No seedlings taller than $1 \mathrm{~m}$ were found in the grazed plots (Fig. S4).

The ground-layer vegetation was taller in the mature $(31.1 \mathrm{~cm}$ [24.2, 38.2]) than reforestation $(27.0 \mathrm{~cm}[19.9,34.1])$ and unforested $(19.7 \mathrm{~cm}[15.4,23.9])$ plots, and taller in the ungrazed $(26.5 \mathrm{~cm}[21.9,31.0])$ than grazed $(18.4 \mathrm{~cm}[13.3,23.6])$ plots (Fig. 1G). The depth of moss was thicker in the ungrazed $(6.45 \mathrm{~cm}[5.1,7.8])$ than grazed $(3.4 \mathrm{~cm}[1.8,5.0])$ plots, and thinner in the reforestation $(4.5 \mathrm{~cm}[2.6,6.4])$ than mature (7.17 cm [4.96, 9.39]) plots (Fig. 1H).

\section{Discussion}

\section{Carbon Balance}

A possible reason for the lower topsoil carbon in the reforestation plots relative to unforested plots is soil carbon loss following reforestation. No baseline measurements were taken prior to reforestation, so unforested areas represented the pre-reforestation state. With relatively slow tree growth aboveground and no trend in soil carbon accumulation over the chronosequence of sites, this suggests net loss of carbon in the early stages of reforestation.

Soil carbon losses following forest establishment are expected in locations with high initial soil carbon and seminatural vegetation cover, often driven by soil disturbance (Mayer et al. 2020). Tree planting on deep peats is avoided to prevent release of carbon from the soil, and emerging evidence suggests negative impacts of planting on carbon-rich organic soils, such as those at our study sites (Morison et al. 2010; Vanguelova et al. 2018; Friggens et al. 2020). An experimental study in Scotland, assessing the effect of planting native trees (Betula spp. or Pinus sylvestris) in single species plots on moorland with organic soils, found soil carbon loss 12 and 39 years after planting, resulting in no net increase in total ecosystem carbon at any sites and a decline at one site (Friggens et al. 2020). In Friggens et al. (2020), the planting density was 40,000 trees/ha (39-year-old site) and 10,000 trees/ha (12-year-old site). Our study sites had initial densities of 119- 
1,549 trees/ha, with the density in study plots $1,100-5,100$ trees/ ha, reflecting the initial planting and subsequent natural regeneration; the signs of significant soil carbon loss at these lower planting densities are notable. Medium and high productivity production forests on peaty soils can achieve net soil carbon storage over multiple production cycles, c. 100 years after the first planting event, with losses from the peat horizon compensated for by inputs to the upper fermentation horizon (Vanguelova et al. 2019; Mayer et al. 2020). Variable, but in some cases significant, amounts of aboveground carbon were accumulated within the first 30 years of reforestation in our study; the highest aboveground carbon recorded was at the 26-year-old site $\left(7.3 \mathrm{~kg} / \mathrm{m}^{2}\right.$ ), while the oldest sites (28 years old) had 1.2 and $2.8 \mathrm{~kg} / \mathrm{m}^{2}$ of aboveground carbon. With a trajectory of carbon accumulation aboveground in the reforestation sites, we would expect aboveground carbon to increase to the levels seen in the mature forest in our study.

Soil disturbance during forest establishment can cause soil carbon loss, driven by erosion, oxidation, decomposition, and leaching (Vanguelova et al. 2018; Mayer et al. 2020). Extensive disturbance during establishment of production forest leads to large soil carbon losses, whereas hand planting disturbs c. $2 \%$ of the soil, causing smaller soil carbon losses (Vanguelova et al. 2018). Most of our study sites were hand planted, but the three youngest sites were prepared by machine mounding (a digger inverted small mounds of soil into which the trees were planted). There was no evidence for lower topsoil carbon at these three sites and one had the highest soil carbon recorded.

Biotic factors also determine the soil carbon balance and there is evidence that tree establishment can alter the soil microbial and mycorrhizal fungi communities, influencing the carbon balance, which may explain soil carbon losses at our study sites. Microbes play a key role in soil carbon storage, transforming labile carbon into more stable forms, while microbial respiration and breakdown of carbon by extracellular enzymes can contribute to carbon loss from the soil (Wiesmeier et al. 2019; Mayer et al. 2020). The experimental investigation of tree planting on organic soils found higher soil respiration at the sites planted with trees compared to heather moorland, potentially explaining the loss of soil carbon (Friggens et al. 2020). A hypothesis is that this was driven primarily by a shift in the mycorrhizal fungi community and stimulation of the soil microbial community by recent carbon inputs into the soil (Brzostek et al. 2013; Friggens et al. 2020). Further work suggests that nitrogen mining by ectomycorrhizal fungi can drive higher turnover of soil carbon stocks under forest soils (Clemmensen et al. 2021).

Our study is limited by a lack of baseline data. The literature supports the hypothesis that the lower topsoil carbon in the reforestation sites represents loss of soil carbon, particularly as the study sites have peaty soils and were previously vegetated (Guo \& Gifford 2002; Friggens et al. 2020; Matthews et al. 2020). We matched the unforested plots representing the baseline condition to the reforestation plots, but we cannot rule out that the reforestation sites had lower soil carbon prior to reforestation. For example, drier areas of the reforestation sites were targeted for planting and the unforested, ungrazed plots may not represent the prior condition as well as the unforested, grazed plots, where we were less constrained in matching these to the reforestation plots. We found a less clear difference in topsoil carbon between the unforested, grazed plots and the reforestation plots, with the $95 \%$ confidence interval including zero, although extending to $19 \mathrm{~kg} / \mathrm{m}^{2}\left(-1.37,19.02 \mathrm{~kg} / \mathrm{m}^{2}\right)$. If the reforestation sites had lower initial soil carbon than the ungrazed areas, then the aboveground accumulation of biomass in the trees will lead to net carbon gain. These challenges in interpretation highlight the need to monitor soil carbon within reforestation projects.

Soil samples taken to greater depths and a larger number of samples from each site would provide a clearer picture of overall carbon changes and allow soil carbon to be quantified within each soil horizon (Vanguelova et al. 2016). This would also allow us to assess whether losses in the upper horizons were compensated for by inputs at greater depths (Vanguelova et al. 2018). Additionally, as reforestation at our study sites is heterogeneous, an overall assessment of the carbon balance would need to consider soil carbon and the variable tree establishment success and growth rates across the entirety of each site. More data are needed to understand the long-term response of soil carbon to reforestation, the management factors that influence soil carbon and how strategies such as natural forest regeneration might mitigate the risk of soil carbon loss.

\section{The Response of Other Ecosystem Functions}

Carbon storage is an important ecosystem service derived from reforestation and explicit target of many reforestation projects (Lewis et al. 2019), but it is important to understand how other functions linked to wider aspects of the ecosystem respond (Aerts \& Honnay 2011). Reforestation has the potential to influence multiple belowground processes, with consequences for soil quality and the soil community (Jackson et al. 2000; Amacher et al. 2007; Ashwood et al. 2019). Aboveground, the future of the forest will depend on the regeneration of seedlings (Cook-Patton et al. 2020; García et al. 2020) and the structure of the understorey can be important in determining habitat availability (Fuller et al. 2018).

As planted Betula pubescens establishes on moorland in Scotland, it can trigger changes to soil properties, for example, increasing fertility, decomposition rates, and the availability of mineralizable nitrogen (Mitchell et al. 2007; Mitchell et al. 2010). We found that soil nitrogen was highest in the unforested areas and higher in the ungrazed than grazed areas, giving no indication that nitrogen availability has increased with forest establishment.

Decomposition rates in our study were highest in the unforested and lowest in the mature forest areas, with rates in the reforestation areas not clearly different from the other two habitats. There is evidence that tree-associated mycorrhizal fungi can increase decomposition of litter in the soil (Clemmensen et al. 2021). The trends in decomposition rates across habitat types do not correspond with this, however. But it would be valuable to confirm our decomposition rates over a longer time period. 
Forest establishment on moorland in Scotland led to an increase in the abundance of soil predators such as nematodes and increased microarthropod abundance (Mitchell et al. 2007; Mitchell et al. 2010). This contrasts with the results of our bait lamina experiment, which found lower invertebrate feeding activity at the reforestation sites.

Seedling regeneration occurred at very low levels in the unforested plots, despite these plots being located within $400 \mathrm{~m}$ of reforestation sites. Grazing intensity by deer and ground cover favorability are more important than presence of a seed source for Betula spp. regeneration in the Scottish Highlands (Tanentzap et al. 2013). In our study, in the grazed, unforested areas deer grazing pressure negatively impacts seedling regeneration and in the ungrazed, unforested areas the higher ground vegetation due to grazing release may suppress seedling regeneration. In the grazed, mature plots high abundances of seedlings, particularly Sorbus aucuparia in one plot, were found despite the grazing pressure, potentially reflecting seed dispersal by birds, but were restricted to the smallest height categories, highlighting the threat that grazing presents in mature woodland (García et al. 2020).

The ground vegetation and moss layer were lower in the reforestation plots. This could reflect low light availability under the typically denser tree cover in these plots (Dormann et al. 2020). A tall ground layer dominated by ericaceous shrubs and a thick moss layer is characteristic of mature Caledonian pinewood, but the reforestation sites do not appear to have developed these, despite characteristic species being present (Mason et al. 2004; Warner et al. 2021). Development of the understorey will play a key role in forest functioning, as well as providing food, habitat and shelter for a range of organisms (Landuyt et al. 2019).

The less clear directional shift in belowground functions and processes in our study compared to the experimental investigation may reflect the contrast between a controlled experimental study with high-density single species planting (40,000 trees/ha) and our study assessing lower density reforestation (1,100-5,100 trees/ha in study plots) across a more heterogeneous landscape (Mitchell et al. 2007; Mitchell et al. 2010). Despite this, the conservation project used in our study might better represent planned native reforestation in the Scottish Highlands. We suggest that the results from experimental studies must be upscaled with caution in predicting likely outcomes from real world reforestation projects.

\section{Planning Future Reforestation}

The reforestation project studied here began in 1990 with the objective of restoring areas of native Caledonian pinewood. During its lifetime, interest in forest expansion has grown globally, including in the United Kingdom, where expansion has occurred most quickly in Scotland (Forest Research 2020). Forest expansion usually aims to meet multiple objectives, but carbon storage is often a key priority. This study contributes evidence that reforestation on high carbon content soils can lead to net carbon losses in the early stages of reforestation. Soil carbon losses must be monitored in similar projects and losses accounted for, with new research needed to assess how losses can be minimized.

Area-based forest expansion targets can provide a risk in meeting carbon sequestration targets if woodland that initially leads to net carbon release is not accounted for in estimates of carbon storage (Matthews et al. 2020). Carbon release from carbon-rich soils is typically attributed to the initial disturbance caused by site preparation. In our study either the minimal soil disturbance is driving soil carbon loss, or other pathways, for example, changes to soil fungal and microbial communities, are driving the losses (Brzostek et al. 2013; Friggens et al. 2020). Forest expansion by natural regeneration could reduce impacts on soil carbon, by avoiding soil disturbance and limiting reforestation of peat soils, which are less favorable for seedling establishment (Limpens et al. 2014). However, carbon accumulation aboveground by natural regeneration can be less predictable and impacts on soil carbon are not well understood. To inform forest expansion ambitions in Scotland, future research should aim to understand aboveground carbon accumulation in naturally regenerating forest, the extent to which trees naturally colonize high carbon content soils, and the impact on soil carbon stocks.

Single-criterion objectives for restoration projects risk compromising gains related to other objectives (Strassburg et al. 2020). Caledonian pinewood is a priority habitat for conservation in the UK and its restoration is critical to the maintenance of associated specialist species (Mason et al. 2004). At our study sites, the value of the reforestation areas for specialist species has been shown (Warner et al. 2021). Future reforestation with conservation objectives is important and carbon targets should not compromise targets for biodiversity. Nonetheless, these projects should be designed in a way to minimize soil carbon release and carbon accounting must be conducted accurately.

\section{Acknowledgments}

The authors are grateful to everyone at Trees for Life for support during fieldwork and particularly to James Rainey for helpful discussions on the context to and interpretation of our study. The authors would like to thank Giles Drake-Brockman, Forestry and Land Scotland, who helped to facilitate fieldwork. Many thanks to Sarah Warner and Tony Henry for additional help with data collection. The authors would like to thank the reviewer and editor, Stephen Murphy, for their comments on the manuscript. Emily Warner's PhD is funded by the Natural Environment Research Council NE/L002612/1. Data will be archived in the NERC Environmental Information Data Centre.

\section{LITERATURE CITED}

\footnotetext{
Aerts R, Honnay O (2011) Forest restoration, biodiversity and ecosystem functioning. BMC Ecology 11:1-10

Amacher MC, O’Neill KP \& Perry CH (2007) Soil vital signs: a new soil quality index (SQI) for assessing forest soil health. USDA Forest Service Research Paper

Ashwood F, Watts K, Park K, Fuentes-Montemayor E, Benham S, Vanguelova EI (2019) Woodland restoration on agricultural land: longterm impacts on soil quality. Restoration Ecology 27:1381-1392
} 
Bates D, Machler M, Bolker B, Walker S (2015) Fitting linear mixed-effects models using lme4. Journal of Statistical Software 67:1-48

Brzostek ER, Greco A, Drake JE, Finzi AC (2013) Root carbon inputs to the rhizosphere stimulate extracellular enzyme activity and increase nitrogen availability in temperate forest soils. Biogeochemistry 115:65-76

Clemmensen KE, Durling MB, Michelsen A, Hallin S, Finlay RD, Lindahl BD (2021) A tipping point in carbon storage when forest expands into tundra is related to mycorrhizal recycling of nitrogen. Ecology Letters 24: $1193-1204$

Committee on Climate Change (2020) Land use: Policies for a Net Zero UK. UK Committee on Climate Change Report. https://www.theccc.org.uk/ publication/land-use-policies-for-a-net-zero-uk/\%0A (accessed 15/12/ 2020)

Cook-Patton SC, Leavitt SM, Gibbs D, Harris NL, Lister K, AndersonTeixeira KJ, et al. (2020) Mapping carbon accumulation potential from global natural forest regrowth. Nature 585:545-550

Dave R, Saint-Laurent C, Moraes M, Simonit S, Raes L \& Karangwa C (2017) Bonn Challenge Barometer of Progress: Spotlight Report. https://portals. iucn.org/library/sites/library/files/documents/2017-060.pdf (accessed 19/ 03/2019)

Di Sacco A, Hardwick K, Blakesley D, Brancalion PHS, Breman E, Rebola LC, et al. (2021) Ten golden rules for reforestation to optimise carbon sequestration, biodiversity recovery and livelihood benefits. Global Change Biology 27:1328-1348

Dormann CF, Bagnara M, Boch S, Hinderling J, Janeiro-Otero A, Schäfer D, Schall P, Hartig F (2020) Plant species richness increases with light availability, but not variability, in temperate forests understorey. BMC Ecology 20:1-9

Forest Research (2020) Forestry statistics 2020. Edinburgh

Friggens NL, Hester AJ, Mitchell RJ, Parker TC, Subke JA, Wookey PA (2020) Tree planting in organic soils does not result in net carbon sequestration on decadal timescales. Global Change Biology 26: $5178-5188$

Fuller L, Fuentes-Montemayor E, Watts K, Macgregor NA, Bitenc K, Park KJ (2018) Local-scale attributes determine the suitability of woodland creation sites for Diptera. Journal of Applied Ecology 55:1173-1184

García C, Espelta JM, Hampe A (2020) Managing forest regeneration and expansion at a time of unprecedented global change. Journal of Applied Ecology 57:2310-2315

Guo LB, Gifford RM (2002) Soil carbon stocks and land use change: a meta analysis. Global Change Biology 8:345-360

HM Government (2020) The ten point plan for a Green industrial revolution. HM Government Report

International Organization for Standardization (1995) ISO 10694 Soil quality Determination of organic and total carbon after dry combustion (elementary analysis). https://www.iso.org/standard/18782.html

International Organization for Standardization (1998) ISO 13878 Soil quality Determination of total nitrogen content by dry combustion ("elemental analysis"). https://www.iso.org/standard/23117.html

Jackson RB, Schenk HJ, Jobbagy EG, Canadell J, Colello GD, Dickinson RE, et al. (2000) Belowground consequences of vegetation change and their treatment in models. Ecological Applications 10:470-483

Keuskamp JA, Dingemans BJJ, Lehtinen T, Sarneel JM, Hefting MM (2013) Tea bag index: a novel approach to collect uniform decomposition data across ecosystems. Methods in Ecology and Evolution 4:1070-1075

Kollmann J, Meyer ST, Bateman R, Conradi T, Gossner MM, de Souza Mendonça M, et al. (2016) Integrating ecosystem functions into restoration ecology-recent advances and future directions. Restoration Ecology 24:722-730

Kratz W (1998) The bait-lamina test general aspects, applications and perspectives. Environmental Science and Pollution Research 5:94-96

Landuyt D, De Lombaerde E, Perring MP, Hertzog LR, Ampoorter E, Maes SL, et al. (2019) The functional role of temperate forest understorey vegetation in a changing world. Global Change Biology 25:3625-3641
Lewis SL, Wheeler CE, Mitchard ETA, Koch A (2019) Restoring natural forests is the best way to remove atmospheric carbon. Nature 568:25-28

Limpens J, Van Egmond E, Li B, Holmgren M (2014) Do plant traits explain tree seedling survival in bogs? Functional Ecology 28:283-290

Mason WL, Hampson A, Edwards C (2004) Managing the pinewoods of Scotland. Forestry Commission, Edinburgh, Scotland

Matthews G (1993) Forestry Commission Technical Paper: The carbon content of trees. https://www.forestry.gov.uk/PDF/FCTP004.pdf/\$FILE/FCTP004.pdf (accessed 25/01/2019)

Matthews KB, Wardell-Johnson D, Miller D, Fitton N, Jones E, Bathgate S, Randle T, Matthews R, Smith P, Perks M (2020) Not seeing the carbon for the trees? Why area-based targets for establishing new woodlands can limit or underplay their climate change mitigation benefits. Land Use Policy 97:104690

Mayer M, Prescott CE, Abaker WEA, Augusto L, Cécillon L, Ferreira GWD, et al. (2020) Influence of forest management activities on soil organic carbon stocks: a knowledge synthesis. Forest Ecology and Management 466:118127

Milne R, Brown TA (1997) Carbon in the vegetation and soils of Great Britain. Journal of Environmental Management 49:413-433

Mitchell RJ, Campbell CD, Chapman SJ, Cameron CM (2010) The ecological engineering impact of a single tree species on the soil microbial community. Journal of Ecology 98:50-61

Mitchell RJ, Campbell CD, Chapman SJ, Osler GHR, Vanbergen AJ, Ross LC, Cameron CM, Cole L (2007) The cascading effects of birch on heather moorland: a test for the top-down control of an ecosystem engineer. Journal of Ecology 95:540-554

Mitchell RJ, Keith AM, Potts JM, Ross J, Reid E, Dawson LA (2012) Overstory and understory vegetation interact to alter soil community composition and activity. Plant and Soil 352:65-84

Morison J, Matthews R, Miller G, Perks M, Randle T, Vanguelova E, White M, Yamulki S (2012) Understanding the carbon and greenhouse gas balance of forests in Britain. Forestry Commission Research Report

Morison J, Vanguelova E, Broadmeadow S, Perks M, Yamulki S, Randle T (2010) Understanding the GHG implications of forestry on peat soils in Scotland. Forestry Commission Scotland Report

Muukkonen P, Mäkipää R (2006) Biomass equations for European trees: addendum. Silva Fennica 40:763-773

Patterson G, Nelson D, Robertson P, Tullis J (2014) Scotland's native woodlands results from the native woodland survey of Scotland. Forestry Commission Scotland Report

R Core Team (2019) R: a language and environment for statistical computing. R Core Team, Vienna, Austria. https://www.r-project.org/

Seddon N, Turner B, Berry P, Chausson A, Girardin CAJ (2019) Grounding nature-based climate solutions in sound biodiversity science. Nature Climate Change 9:84-87

Strassburg BBN, Iribarrem A, Beyer HL, Cordeiro CL, Crouzeilles R, Jakovac CC, et al. (2020) Global priority areas for ecosystem restoration. Nature 586:724-729

Tanentzap AJ, Zou J, Coomes DA (2013) Getting the biggest birch for the bang: restoring and expanding upland birchwoods in the Scottish Highlands by managing red deer. Ecology and Evolution 3:1890-1901

Thomas HJD, Paterson JS, Metzger MJ, Sing L (2015) Towards a research agenda for woodland expansion in Scotland. Forest Ecology and Management 349:149-161

Tipping R, Davies A, Tisdall E (2006) Long-term woodland dynamics in West Glen Affric, northern Scotland. Forestry 79:351-359

Vanguelova E, Chapman S, Perks M, Yamulki S, Randle T, Ashwood F \& Morison J (2018) Afforestation and restocking on peaty soils - new evidence assessment. ClimateXChange:1-43. Available from www.climatexchange.org.uk (accessed 11/12/2020)

Vanguelova EI, Bonifacio E, De Vos B, Hoosbeek MR, Berger TW, Vesterdal L, et al. (2016) Sources of errors and uncertainties in the assessment of forest soil carbon stocks at different scales-review and recommendations. Environmental Monitoring and Assessment 188:630

Vanguelova EI, Crow P, Benham S, Pitman R, Forster J, Eaton EL, Morison JIL (2019) Impact of Sitka spruce (Picea sitchensis (Bong.) Carr.) afforestation 
on the carbon stocks of peaty gley soils - a chronosequence study in the north of England. Forestry 92:242-252

Vanguelova EI, Nisbet TR, Moffat AJ, Broadmeadow S, Sanders TGM, Morison JIL (2013) A new evaluation of carbon stocks in British forest soils. Soil Use and Management 29:169-181

Warner E, Hector A, Brown N, Green R, Savory A, Gilbert D, McDonnell A, Lewis OT (2021) The response of plants, carabid beetles and birds to 30 years of native reforestation in the Scottish Highlands. Journal of Applied Ecology 00:1-10

Wiesmeier M, Urbanski L, Hobley E, Lang B, von Lützow M, Marin-Spiotta E, et al. (2019) Soil organic carbon storage as a key function of soils - a review of drivers and indicators at various scales. Geoderma 333:149-162

Zianis D, Muukkonen P, Mäkipää R, Mencuccini M (2005) Biomass and stem volume equations for tree species in Europe. Silva Fennica Monographs 4:1-63

\section{Supporting Information}

The following information may be found in the online version of this article:

Supplement S1. Calculation of decomposition rate constant, $k$.

Figure S1. The location of the fenced reforestation sites used in this study.

Figure S2. Close up of the site Am Meallan, showing the locations of the survey plots.

Figure S3. (A) The response of soil carbon to plot type (factor with five levels) and (B) change over time in the difference in topsoil carbon between the paired reforestation, ungrazed plots and the unforested, grazed plots $(n=12)$

Figure S4. Frequency of seedlings per plot for each tree species, by seedling height category $(<50,50-100,100-150$, and $>150 \mathrm{~cm})$.

Table S1. Information on the focal fenced and reforestation sites in this study.

Table S2. Allometric equations used to calculate tree biomass in each plot.

Table S3. Response variables and units for each ecosystem function measured.

Received: 6 April, 2021; First decision: 12 May, 2021; Revised: 17 August, 2021; Accepted: 17 August, 2021 